\title{
THREE NEW LEPANTHES (ORCHIDACEAE: PLEUROTHALLIDINAE) FROM SOUTH-EAST COSTA RICA
}

\author{
Diego Bogarín ${ }^{1,2,5}$, Adam P. Karremans ${ }^{1,3}$ \& Franco Pupulin ${ }^{1,4}$ \\ ${ }^{1}$ Jardín Botánico Lankester, Universidad de Costa Rica, P. O. Box 302-7050 Cartago, Costa Rica. \\ ${ }^{2}$ Herbario UCH, Universidad Autónoma de Chiriquí, P.O. Box 0427, Chiriquí, Panamá. \\ ${ }^{3}$ NCB Naturalis - NHN Universiteit Leiden, The Netherlands. \\ ${ }^{4}$ Harvard University Herbaria, 22 Divinity Avenue, Cambridge, Massachusetts, U.S.A.; Marie Selby \\ Botanical gardens, Sarasota, FL, U.S.A. \\ ${ }^{5}$ Corresponding author: diego.bogarin@ucr.ac.cr
}

\begin{abstract}
Aвstract. Three new species of Lepanthes from south-east Costa Rica are described and illustrated. Lepanthes erubescens resembles $L$. limbellata, from which it can be distinguished by the pendent plants, with inflorescences that borne above the leaf, the upper petal lobe ovate, acute, $1,3 \mathrm{~mm}$ wide, larger than the lower lobe, and the ovate lip. Lepanthes sandiorum resembles L. dolabriformis, however it can be distinguished by the smaller plants, the smaller flowers, the narrower petals, which are filiform, with the upper lobe oblong, rounded, entire and glabrous. Lepanthes sanjuanensis is similar to L. elegans, but it is distinguished by the green-purple, un-reticulated leaves, the petals with the upper lobe oblong, rounded, with the margins red, the lower lobe oblong, rounded, divergent at apex, and the pinkish or orange-red lip. Additional comments on the species are provided.
\end{abstract}

Key words: Orchidaceae, Pleurothallidinae, Lepanthes erubescens, Lepanthes sandiorum, Lepanthes sanjuanensis, new species, taxonomy

Lepanthes comprises about 120 species in Costa Rica. The taxonomic history of the genus in the counry began with the arrival of the explorers A. Oersted and $\mathrm{H}$. Wendland in the second half of the nineteenth century. They collected Lepanthes between 1855 and 1857, mostly at El Desengaño and Cartago, along the mountains of the Valle Central. H.G Reichenbach $f$. described 8 new species from among their collections (Reichenbach 1866). From that same year and up to 1874 , botanist Auguste R. Endrés thoroughly explored Costa Rica, documenting almost half of the known species of Lepanthes now reported from the country. Endrés gathered more than 250 specimens, corresponding to 63 species and prepared 201 illustrations (Pupulin et al. 2011). Unfortunately his work was never published and at least 55 species of Lepanthes remained undescribed until Luer (1995) studied his material kept at $\mathrm{W}$.

Between 1912 and 1923, R. Schlechter published 18 species based on material collected in Costa Rica. The material was gathered mostly by $\mathrm{G}$. Acosta, the brothers A. and C. Brade, A. Brenes, H.
Pittier, A. Tonduz and C. Wercklé (Schlechter 1923). Contemporarily, O. Ames, who received material from C. Lankester, also added about 22 species to the genus (Ames 1923). After the pasing of O. Ames and R. Schlechter, the description of new orchid species in Costa Rica declined considerably. No Lepanthes species were described during the next 53 years.

Luer (1983) began to describe new Lepanthes species based on his own field work activities since 1981, but mainly from studying Endrés' material that remained forgotten for over a century. Indeed, even with the contributions of Reichenbach, Schlechter and Ames, the diversity of Lepanthes was far from being understood. Luer (1996) added 70 species (almost doubling the number of species known to date) to the flora of Costa Rica. About 21 of them were based on the collections by Endrés (Luer 1995).

After Luer (1995, 1996), and with the turn of the century, research at Lankester Botanical Garden (JBL) has revealed some 22 new species of Lepanthes. Those studies mostly covered areas not visited by the traditional collectors mentioned previously (Pupulin 
et al. 2010). The area that comprises the Southern Pacific watershed of the Talamanca mountain range, from the foothills of Cerro de la Muerte and Chirripó, neighboring the Valle de El General, Fila Costeña and up to the border with Panama, in the Costa Rican south-east, is very rich in Lepanthes species.

Here we propose three new species from this region of Costa Rica:

Lepanthes erubescens Bogarín, Pupulin \& Karremans, sp. nov.

Type: Costa Rica. San José: Pérez Zeledón, Santa Elena de El General, Quebrada Los Granados, 710 m, collected by Vicente Juárez-Pérez, 17 March 2002, flowered in cultivation at Jardín Botánico Lankester, 29 June 2002, F. Pupulin 4027 (holotype, JBL). FIg. $1,4 \mathrm{~A}$.

A Lepanthes limbellata Endrés ex Luer similis, sed planta pendula, inflorescentiis folii portatis adaxialibus, lobo superno petalorum ovato acuto latiore lobum inferum superantibus et lobulis labelli ovatis.

Plant epiphytic, caespitose, pendent, up to $15 \mathrm{~cm}$ tall. Roots slender, flexuous, to $0.5 \mathrm{~mm}$ in diameter. Ramicauls slender, pendent, $4.5-12 \mathrm{~cm}$ long, enclosed by 8 minutely ciliate, lepanthiform blackish sheaths, the ostia minutely ciliate, ovate, acute, adpressed. Leaves coriaceous, elliptic to ovate or suborbicular, acute to subacuminate, emarginate, with a short apiculus, purplish-green, $2.5-4.0 \times 1.5-2.6 \mathrm{~cm}$, the rounded base narrowing into a petiole less than $3 \mathrm{~mm}$ long. Inflorescence racemose, distichous, glabrous, successively flowered, born above the leaf, shorter than the leaves, up to $2.7 \mathrm{~cm}$ long, peduncle 1.9 $\mathrm{cm}$ long, rachis $0.8 \mathrm{~cm}$ long. Floral bracts ovate, acuminate, conduplicate, membranaceous, $1 \mathrm{~mm}$ long, muriculate. Pedicels $2 \mathrm{~mm}$ long, persistent. Ovary to $2 \mathrm{~mm}$ long, glabrous. Flowers with yellowish-orange sepals, the petals scarlet red, the upper lobe with a yellow stain, the lip reddish-pink, the column scarlet. Dorsal sepal ovate, acute, entire, dorsally with three keels, connate to the lateral sepals for about $0.6 \mathrm{~mm}, 3.6 \times 2.2 \mathrm{~mm}$. Lateral sepals narrowly ovate to elliptic, acute, entire, dorsally with three ciliate keels, connate for $0.8 \mathrm{~mm}, 3.6 \times$
$1.8 \mathrm{~mm}$. Petals transversely bilobed, entire, $5.0 \times$ $1.3 \mathrm{~mm}$, the upper lobe ovate, acute, the lower lobe ovate, narrowly triangular, narrower and shorter than the upper lobe. Lip bilobate, adnate to the column, the blades ovate with rounded ends, embracing the column $1.3 \times 1.7 \mathrm{~cm}$, the connectives terete, oblong, to $0.3 \mathrm{~mm}$ long, the body thick, oblong, rounded, connate to the base of the column, the appendix thick, oblong, pubescent, cylindric. Column cylindric, to 2 $\mathrm{mm}$ long, mucronate, the anther apical and the stigma ventral. Pollinia two, ovoid. Anther cap, triangular, cucullate.

Paratypes: Costa Rica. Puntarenas: Buenos Aires, Volcán, $09^{\circ} 13^{\prime} \mathrm{N}, 83^{\circ} 26^{\prime} \mathrm{W}$, ca. $450 \mathrm{~m}$, bosque muy húmedo premontano transición a basal en bosque secundario muy alterado a orillas de un riachuelo, 17 abril 2012, A.P. Karremans 5312, J. Cambronero \& J. Gemmel (JBL-Spirit!) Same locality and date, A.P. Karremans 5314 (JBL-Spirit!). San José: Pérez Zeledón, El Alto de San Juan, ca. 1300 m, collected by Jeremy Quesada Gonzalez, flowered in cultivation in the collection of Daniel Jiménez at Paraíso de Cartago, 12 Julio 2012, J. Quesada s.n. (JBL-Spirit!).

Distribution: known from south-east Costa Rica, on the Pacific watershed of the Talamanca mountain range.

Habitat and ecology: epiphytic in secondary forest in premontane wet forest, basal belt transition, premontane wet forest and premontane moist forest, at 450-1150 $\mathrm{m}$ of elevation.

EPONYMY: from the Latin erubescens "reddening, blushing" in reference to the scarlet red color of the petals.

Lepanthes erubescens resembles $L$. limbellata Endrés ex Luer. However, it can be distinguished mainly by the the pendent plants (vs. erect), with inflorescences that is borne above the leaf (vs. behind), the upper lobe ovate, acute, $1.3 \mathrm{~mm}$ wide, larger than the lower lobe (vs. narrowly ovate-triangular, narrowly obtuse, $0.6 \mathrm{~mm}$ wide, equal in length to the lower lobe) and the ovate lip blades (vs. narrowly oblong).

Lepanthes sandiorum Bogarín \& Karremans, sp. nov. TyPe: Costa Rica. Puntarenas: Coto Brus, Sabalito, 

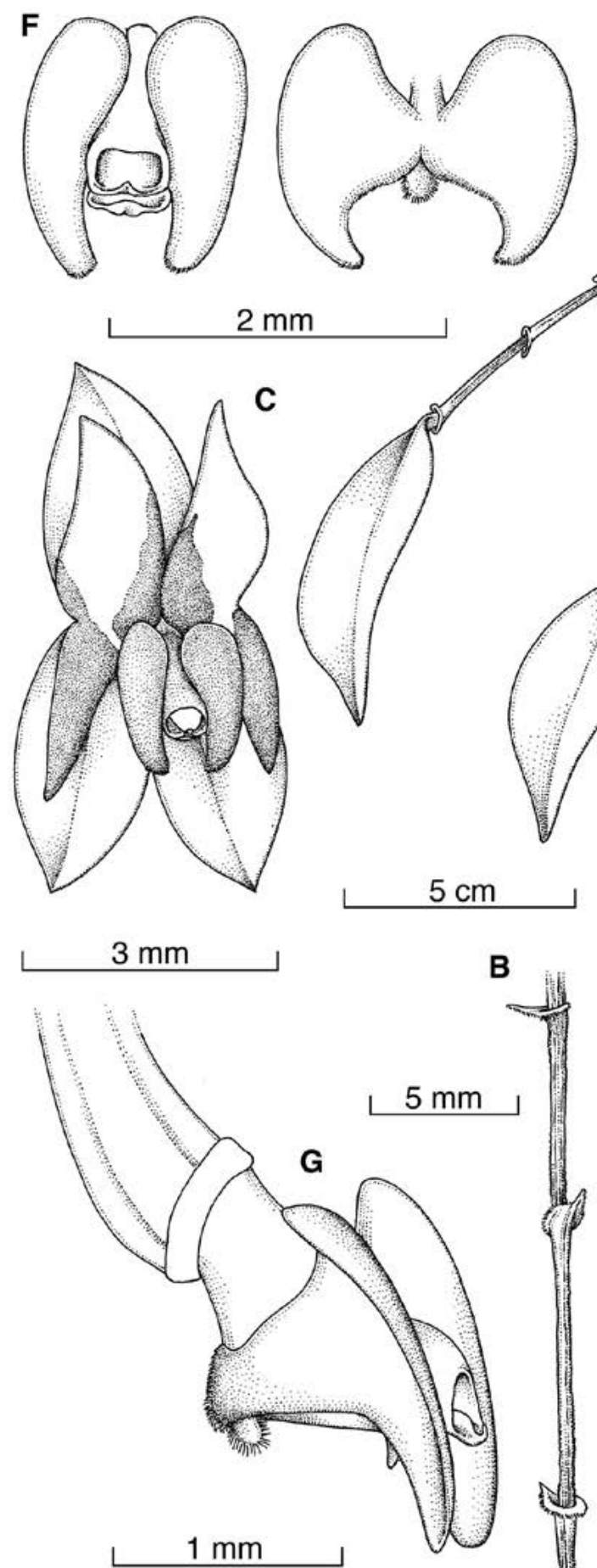

B
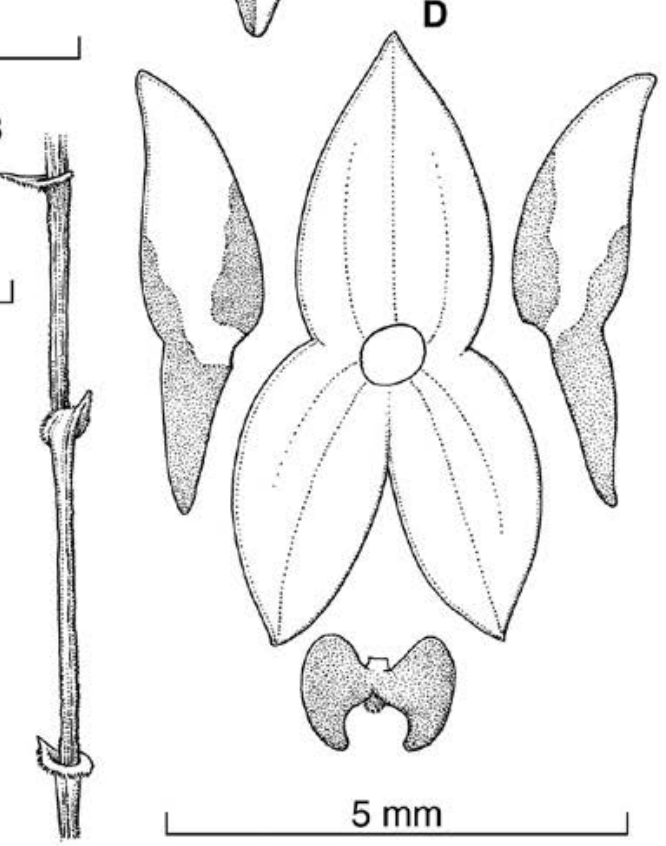

Figure 1. Lepanthes erubescens Bogarín, Pupulin \& Karremans. A - Habit. B - Ramicaul. C - Flower. D - Perianth FLATTEN. E - Apex of petal. F - Lip, front view with the column and spread without the column. G- Lip and column, lateral view. Drawn by D. Bogarín and F. Pupulin from the holotype. 
Zona Protectora Las Tablas, $13 \mathrm{~km}$ al noreste de Lucha, Sitio Coto Brus, entre Río Surá y Quebrada Sutú, Finca de Miguel Sandí, 856’46.1” N 8244’30.9” W, 1778 $\mathrm{m}$, bosque pluvial montano bajo, epífitas en potreros arbolados, 6 junio 2010, D. Bogarín 7773 \& A.P. Karremans (holotype, JBL-Spirit!). FIG. 2, 4B.

Species Lepanthi dolabriformi Luer similis, distincta habito perparvo, floribus in diametro brevioribus, petalis angustis filiformis et lobo superno petalorum oblongo, rotundato, glabro.

Plant epiphytic, caespitose, suberect, up to $5.5 \mathrm{~cm}$ tall. Roots slender, flexuous, to $0.5 \mathrm{~mm}$ in diameter. Ramicauls slender, erect, $2.3-3.5 \mathrm{~cm}$ long, enclosed by 7 glabrous, lepanthiform sheaths, the ostia minutely ciliate, ovate, acute, adpressed. Leaves coriaceous, elliptic to ovate or suborbicular, obtuse, emarginate, with a short apiculus, purplish beneath, 1.3-1.7 × $0.6-$ $1.4 \mathrm{~cm}$, the rounded base narrowing into a petiole less than $1 \mathrm{~mm}$ long. Inflorescence racemose, distichous, glabrous, successively flowered, born above the leaf, exceeding the leaves, up to $3 \mathrm{~cm}$ long, peduncle 1.5 $\mathrm{cm}$ long, rachis $1.5 \mathrm{~cm}$ long. Floral bracts ovate, acuminate, conduplicate, membranaceous, $1 \mathrm{~mm}$ long, muriculate. Pedicels $2 \mathrm{~mm}$ long, persistent. Ovary to $1 \mathrm{~mm}$ long, glabrous. Flowers with orange sepals, the petals scarlet red with the margin yellow, the lip scarlet with the apex yellow, the column red. Dorsal sepal ovate, acute, denticulate, slightly reflexed, dorsally with three keels, connate to the lateral sepals for about $0.4 \mathrm{~mm}, 2.6 \times 1.4 \mathrm{~mm}$. Lateral sepals narrowly ovate, acute, denticulate, dorsally with three ciliate keels, connate for $0,4 \mathrm{~mm}, 2.6 \times 1.3$ $\mathrm{mm}$. Petals transversely bilobed, entire, glabrous, 0.4 $\times 2.3 \mathrm{~mm}$, the upper lobe oblong, filiform, $1.7 \mathrm{~mm}$ long, rounded, the lower lobe smaller than the upper lobe, to $0.6 \mathrm{~mm}$ long, ovate, obtuse. Lip bilobate, adnate to the column, the blades oblong with rounded ciliolate ends, embracing the column $1.5 \times 1.2 \mathrm{~cm}$, the connectives terete, oblong, to $0.4 \mathrm{~mm}$ long, the body thick, oblong, rounded, connate to the base of the column, the appendix thick, oblong, cylindric. Column cylindric, to $2 \mathrm{~mm}$ long, mucronate, the anther dorsal and the stigma apical. Pollinia two, ovoid, basally filiform. Anther cap, oblong, cucullate.

Paratypes: Costa Rica. Puntarenas: Coto Brus, Sabalito,
Zona Protectora Las Tablas, $13 \mathrm{~km}$ al noreste de Lucha, Sitio Coto Brus, entre Río Surá y Quebrada Sutú, Finca de Miguel Sandí, 8`56'46.1” N 8244'30.9” W, 1778 $\mathrm{m}$, bosque pluvial montano bajo, epífitas en potreros arbolados, 20 abril 2012, A.P. Karremans $5350 \& J$. Gemmel (JBL-Spirit!). Same locality and date, A.P. Karremans 5381 \& J. Gemmel (CR!). Coto Brus, Sabalito, Zona Protectora Las Tablas, $13 \mathrm{~km}$ al noreste de Lucha, Sitio Coto Brus, entre Río Surá y Quebrada Sutú, Finca de Miguel Sandí, 856’46.1"N 8244’30.9" W, $1778 \mathrm{~m}$, bosque pluvial montano bajo, epífitas en potreros arbolados, 6 junio 2010, D. Bogarín 7786 (JBL-Spirit!). Coto Brus, Sabalito, Zona Protectora Las Tablas, 13 km NE of Lucha, Sitio Coto Brus, finca Sandí "El Capricho", 856’46.1” N 8244’30.9” W, 1778 m, epiphytic, mostly on Quercus sp. in pastures and along the river Sutú, wet premontane forest, 6 October 2010, F. Pupulin et al. 7929 (JBL -Spirit!). Same locality and date, F. Pupulin et al. 7930 (JBL -Spirit!). Same locality and date, F. Pupulin et al. 7934 (JBL -Spirit!).Same locality and date, F. Pupulin et al. 7951 (JBL -Spirit!).

Distribution: Endemic to Costa Rica, however, most probably found also in Panama, as the large populations were found growing very close to the border. It is known only from the south-east Costa Rica, on the southernmost portion of the Pacific watershed of the Talamanca mountain range.

Habitat AND ECOLOGY: plants were found growing epiphytically in disturbed lower montane rain forest, at around $1800 \mathrm{~m}$ elevation.

Eponymy: dedicated to Miguel Sandí and his family, pioneers in the region of Las Tablas and owners of the farm where this species was found.

Lepanthes sandiorum resembles $L$. dolabriformis Luer, however it can be distinguished mainly by the smaller plants, less than $5.5 \mathrm{~cm}$ tall (vs. up to $7.5 \mathrm{~cm}$ ), the smaller flowers with sepals $2.6 \times 1.4 \mathrm{~mm}$ (vs. 4.0 $\times 2.5 \mathrm{~mm}$ ), the narrower petals, which are filiform, $2.3 \mathrm{~mm}$ (vs. $3.5-3.75 \mathrm{~mm}$ ) with the upper lobe oblong, rounded, entire, glabrous (vs. obtusely angled with a hatchet-shaped appearance, minutely ciliate, pubescent). Both species are related to L. blepharistes Rchb.f. but they can be easily distinguished by the petals with the lower lobe smaller than the upper lobe (vs. equal in length). 

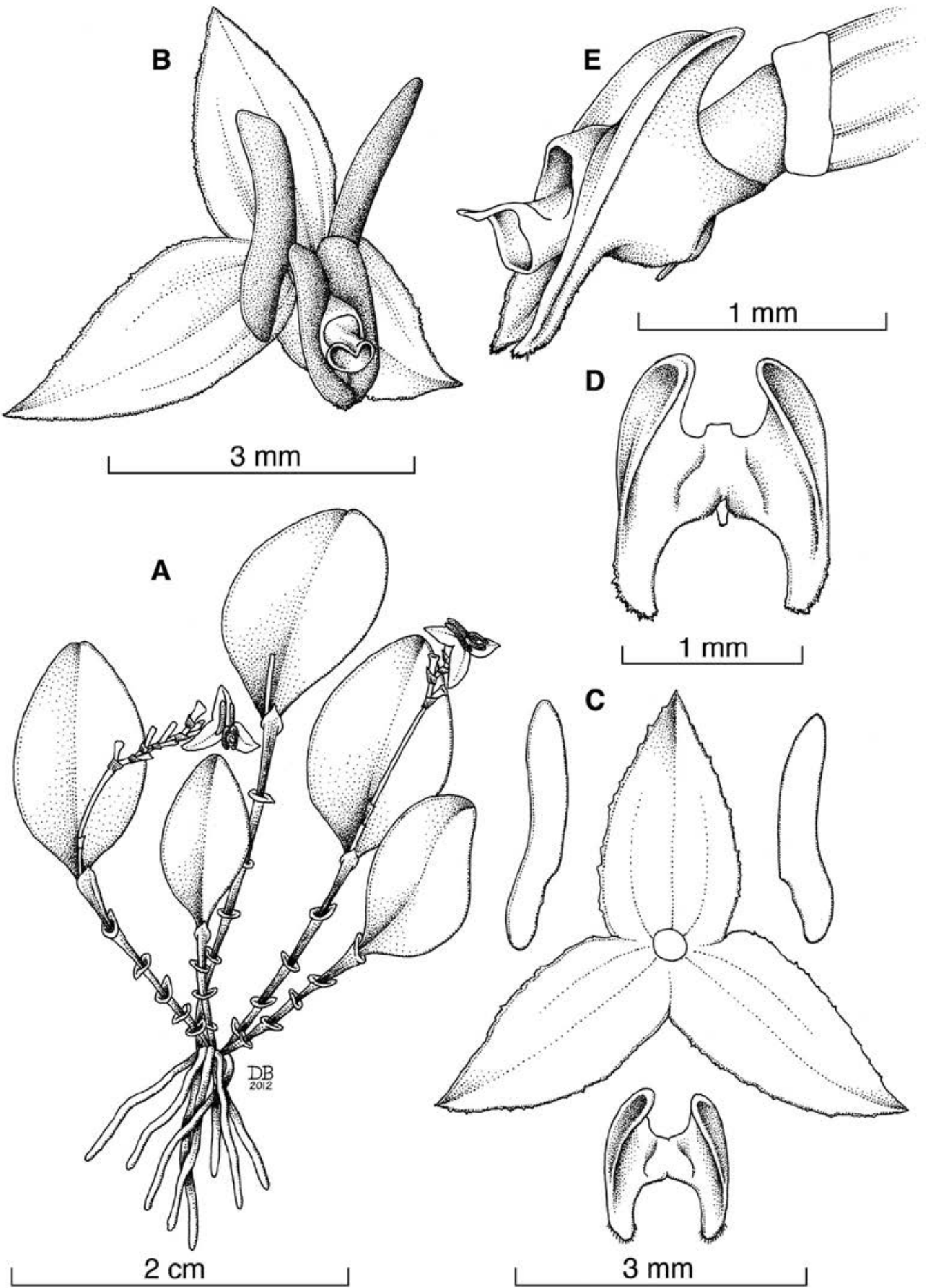

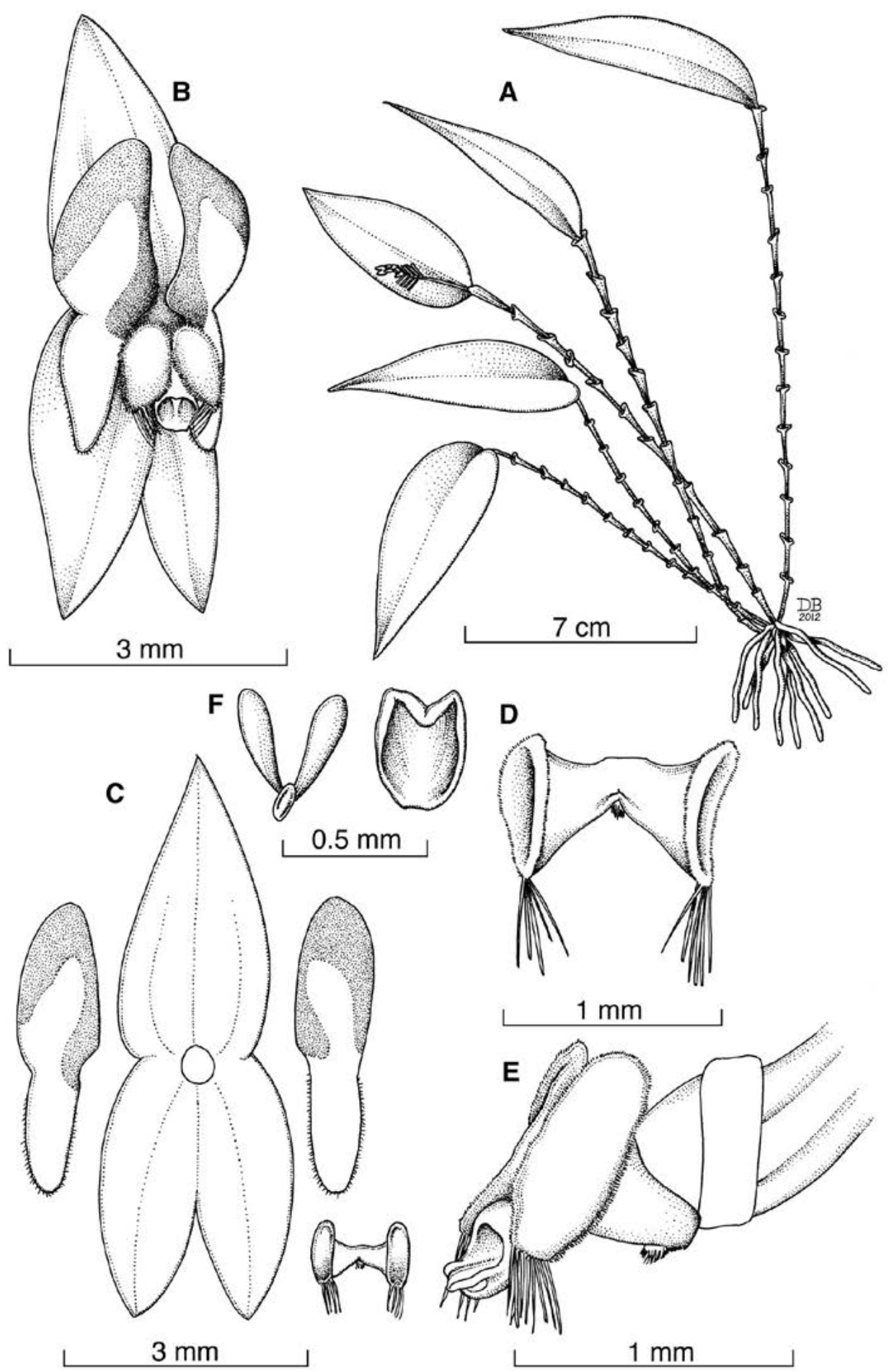

Figure 3. Lepanthes sanjuanensis Bogarín \& Karremans. A - Habit. B - Flower. C - Perianth flatten. D - Lip, spread. E - Column and lip, lateral view. F - Pollinarium and anther cap. Drawn by D. Bogarín from the holotype. 

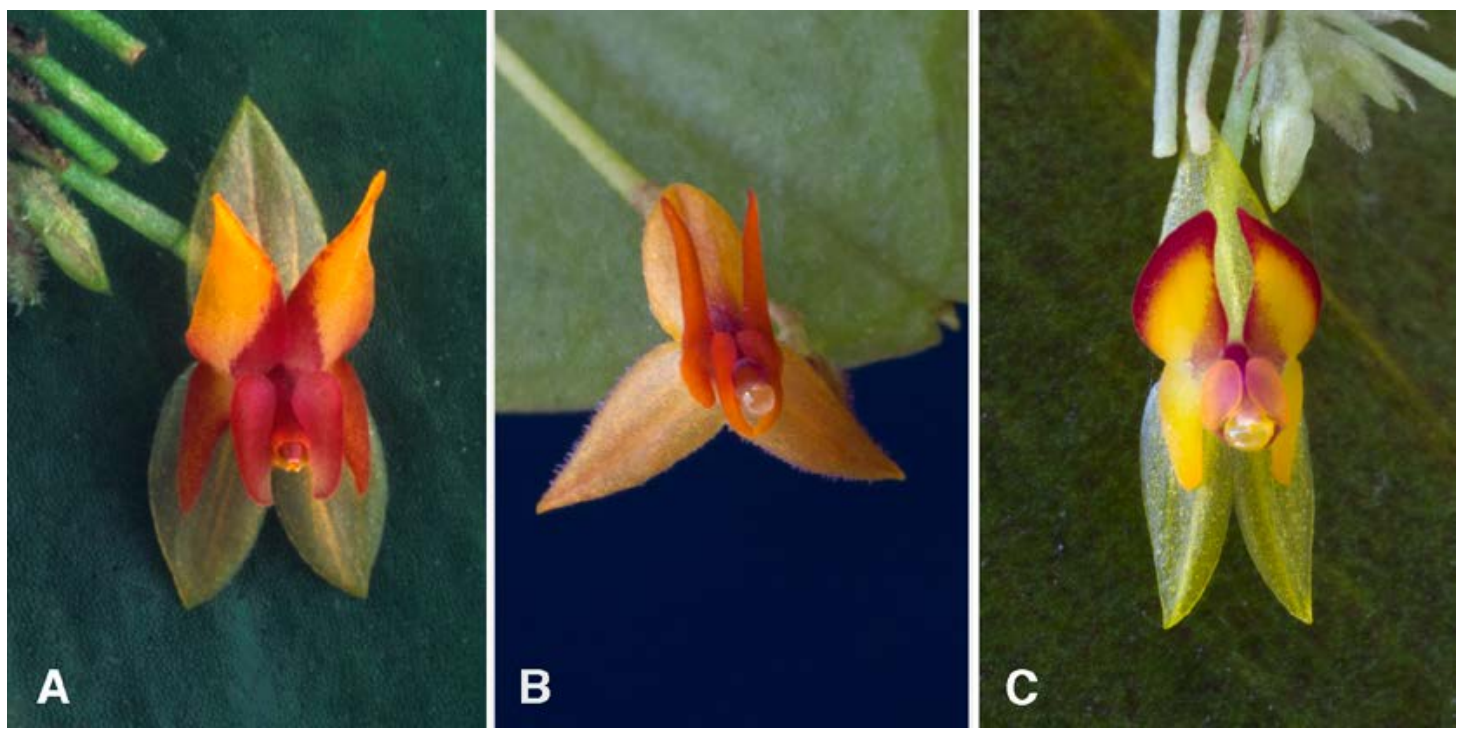

Figure 4. Flowers of the new species of Lepanthes. A-L. erubescens (F. Pupulin 4027). B - L. sandiorum (F. Pupulin 7929). C - L. sanjuanensis (D. Bogarín 7773). Photographs by F. Pupulin (A, B) and D. Bogarín (C).

Lepanthes sanjuanensis Bogarín \& Karremans, sp. nov.

Type: Costa Rica. San José: Pérez Zeledón, San Isidro de El General, carretera a Dominical, desvío hacia el Alto de San Juan, $2 \mathrm{~km}$ al noroeste de la antena, 9²0’36.8’N 8346’07.8’'W, $1187 \mathrm{~m}$, bosque húmedo premontano, sobre árboles en bosque secundario y primario, 3 setiembre 2011, D. Bogarin 9234 \& A.P. Karremans (holotype, JBL!; isotype, CR!). FIG. 3, 4C.

Species habitu cum L. elegans Luer optime congruens, sed foliis purpureis-viridis non reticulatis, lobulis supernis petalorum oblongis, rotundatis, marginibus petalorum rubris, lobulis inferis oblongis, rotundatis, in apice divergentibus et labello rubroaurantiaco differt.

Plant epiphytic, caespitose, pendent or suberect, up to $30 \mathrm{~cm}$ tall. Roots slender, flexuous, to $1 \mathrm{~mm}$ in diameter. Ramicauls slender, suberect, 5-19 cm long, enclosed by $7-12$ minutely ciliate, blackish, tightly adpressed lepanthiform sheaths, the ostia minutely ciliate, ovate, acute, not dilated. Leaves coriaceous, ovate to elliptic, acute to acuminate, emarginate with a short apiculus, conduplicate, adaxially purplish, abaxially purplish-green, not reticulate, $6.0-7.5 \times 3.0$ $3.4 \mathrm{~cm}$, the rounded base narrowing into a petiole less than $3 \mathrm{~mm}$ long. Inflorescence racemose, distichous, glabrous, successively flowered, born beneath the leaf, shorter than the leaves, up to $4 \mathrm{~cm}$ long, peduncle 2-2.5 cm long, rachis $1.0-1.5 \mathrm{~cm}$ long. Floral bracts ovate, acuminate, conduplicate, membranaceous, $1 \mathrm{~mm}$ long, muriculate. Pedicels $5 \mathrm{~mm}$ long, persistent. Ovary to $2 \mathrm{~mm}$ long, glabrous. Flowers with yellow sepals, stained, the petals yellow stained with red along the margin of the upper lobe, the lip pinkish, the column purple-pink basally, yellow apically. Dorsal sepal ovate, acute, entire, dorsally with three keels, connate to the lateral sepals for about $1 \mathrm{~mm}, 1.9 \times 3.7 \mathrm{~mm}$. Lateral sepals narrowly ovate to elliptic, acute, entire, dorsally with three ciliate keels, connate for $1 \mathrm{~mm}$, $3.2 \times 1.2 \mathrm{~mm}$. Petals transversely bilobed, $1.1 \times 3.5$ $\mathrm{mm}$, the upper lobe oblong, rounded, entire, the lower lobe oblong, rounded, ciliate. Lip bilobate, adnate to the column, the blades oblong, ciliolate with rounded ends, the apex of each lobe provided with conspicuous bristles, $0.8 \times 1.2 \mathrm{~cm}$, the connectives terete, oblong, to $5 \mathrm{~mm}$ long, the body thick, oblong, rounded, connate to the base of the column, the appendix pubescent, inconspicuous. Column cylindric, to $1.5 \mathrm{~mm}$ long, mucronate, the anther dorsal and the stigma ventral. Pollinia two, pyriform. Anther cap, oblong, cucullate.

Distribution: only known from south-east Costa Rica, on the Pacific watershed of the Talamanca mountain range. 
Habitat AND ECOLOGY: a population was found epiphytically in premontane moist forest in secondary vegetation, at around 1000-1200 m of elevation.

Eтymology: named after the type locality of Alto de San Juan, along the road from San Isidro de El General to Dominical.

Lepanthes sanjuanensis is similar to L. elegans Luer. Both are characterized by the relatively large plants up to $30 \mathrm{~cm}$ tall, the flowers are small compared to the plant habit, produced below the leaf, and the lip is minute with conspicuous long-ciliate apexes. However, L. sanjuanensis is mainly distinguished by the greenpurple, not reticulated leaves (vs. reticulated), the petals with the upper lobe oblong, rounded, with the margins red (vs. obliquely ovate, with a red blotch at the middle of the upper lobe), the lower lobe oblong, rounded, divergent at apex (vs. obliquely triangular, acute, converging) and the pinkish or orange-red lip (vs. yellow).

ACKNowledgements. We are thankful to the Ministerio del Ambiente, Energía y Telecomunicaciones de Costa Rica (MINAET) and Sistema Nacional de Áreas de Conservación (SINAC) of Costa Rica for issuing the Scientific Passport N. 1862 under which wild specimens treated in this study were collected. To Daniel Jiménez for sharing material and knowledge of the species described. This paper is part of the project "Flora Costaricensis: Taxonomía y filogenia de la subtribu Pleurothallidinae (Orchidaceae) en Costa Rica", 814-BO-052, sponsored by the Vice-Presidency of Research, University of Costa Rica.

\section{LiterATURE CITED}

Ames, O. 1923. Additions to the orchid flora of Central America. Schedul. Orch. 4: 45.

Luer, C.A. 1983. New species of Lepanthes. Phytologia 54: 325-378.

Luer, C.A. 1995. New species of Lepanthes (Orchidaceae) from Costa Rica (with a Biographical note on A.R. Endrés). Lindleyana 10(3):133-175.

Luer, C.A. 1996. New species in the Pleurothallidinae (Orchidaceae) from Costa Rica. Lindleyana 11(2):54-113.

Pupulin, F., D. Bogarín \& C.M. Smith. 2010. Two new species of Lepanthes (Orchidaceae: Pleurothallidinae) close to Lepanthes schizocardia. Lankesteriana 9(3): 423-430.

Pupulin, F., C. Ossenbach, R. Jenny \& E. Vitek. 2011. Typi Orchidacearum ab Augusto R. Endresio in Costa Rica lecti. Ann. Naturhist. Mus. Wien, Ser. B, Bot. Zool. 112: 265-313.

Reichenbach, H.G. 1866. Beiträge zu einer Orchideenkunde Central- Amerika’s. F. Pritzel, Hamburg.

Schlechter, R. 1923. Beiträge zur Orchideenkunde von Zentralamerika, II. Additamenta ad Orchideologiam Costaricensem.

Repert. Sp. Nov. Regni Veg. Beih. 19: 3-307. 